\title{
福井県嶺南地方における山谷風の観測 FIELD OBSERVATION OF MOUNTAIN AND VALLEY WINDS IN THE REINAN AREA OF FUKUI PREFECTURE
}

\author{
玉井昌宏 1 . 有光剛 2 \\ Masahiro TAMAI and Tsuyoshi ARIMITSU

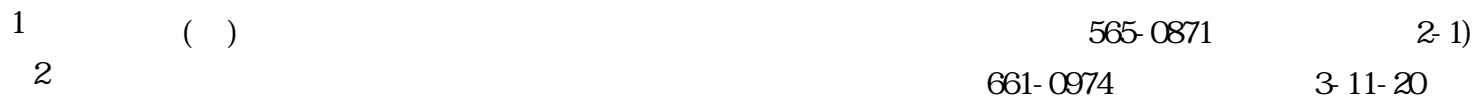

\begin{abstract}
The Reinan area is the western part of Fukui Prefecture and bounded on the north by the Wakasa Bay and on the south by the Nosaka mountains. Valleys in the area connect Wakasa Bay and Lake Biwa areas and wind through the valleys plays important roles in heat and pollutants transports between the two area. Field observation was carried out in Sept., 2004 using a Doppler sodar velocitimeter to investigate structures of mountain and valley winds in one of the valleys. The results were examined in relation to macro- and meso- scale wind fields using the AMeDAS data and the objective analysis data by the JMA.
\end{abstract}

Key Words : Mountain and valley winds, field observation, sea and land breeze, Wakasa Bay

\section{1.はじめに}

大気污染物質のリスク評価法と言えば, 光の手軽さか ら産業技術総合研究所開発のADMER(Atmospheric Dispersion Model for Exposure and Risk Assessment) ${ }^{1}$ が注目 されている.しかしながら，アメダスデータの利用を基 本としているために, 光の精度は地形やアメダスポイン トの配置などに強く影響を受ける . 広大な平野部を除け ば，弚の適用性には問題があると言わざるを得ない. ${ }^{2}$

大気污染源は平野部だけでなく，山間部にも存在する。 沿岸部で生じた污染物質は, 複杂隹な地形の影響を受けな がら，山地部を移動する．こうした状況を再現するため には，3次元数值計算が必須である.さらに，弚れを基 礎としたリスク評価手法を確立するためには, 樣々な気 象条件を相対的に生起確率か高く，かつ大きな被害を及 ぼす可能性のあるような少数のシナリオに集約しておく ことが重要である。

山谷風が海陸風と連動して生じること, 乥れが局地的 集中豪雨に影響していること等々 ${ }^{3}$ ，樣々な知見は得ら れている.しかしながら，限定された条件下におけるも のを除けば，山谷風に関する研究例は少ない . 山のせ まった沿岸地域や山間部での污染シナリオ作成のために は,より一般的な気象条件下での気流場構造の把握が必 須である。
本研究では, 福井県嶺南地方における耳川の谷を吹く 山谷風を観測した .この谷の特徵は, 東西に800級の山 に挟まれており，深く直線的な谷であること，若狭湾沿 岸域と琵琶湖流域を結節する気流の通り路となっている ことか挙げられる．2004年9月に福井県嶺南地方美浜町 の関西電力嶺南発電所においてドップラーソーダ風速計 を用いて, 上空の風向風速を観測した . 地上観測データ， アメダスデータと客観解析データ ( $P V$ データ) を交え て, 谷に吹く風の構造, 発生要因等について検討した。

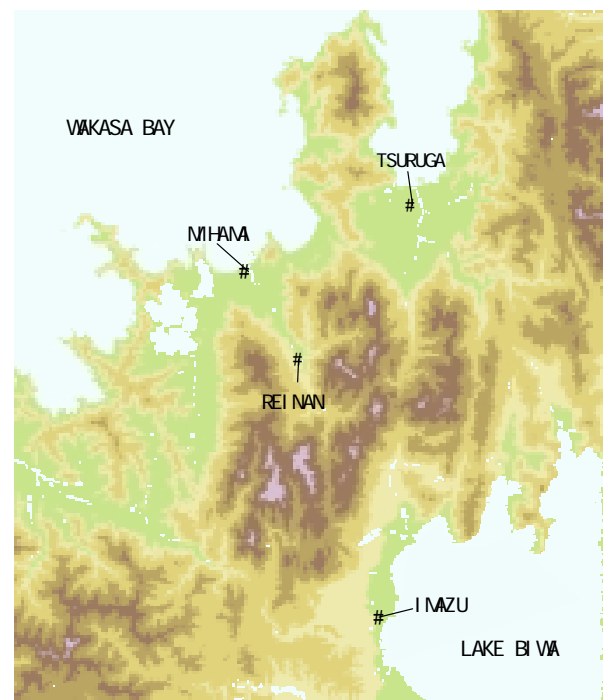

図 - 1 観測地点付近の地形 
わか帼力細長い島国であり，ミクロな谷部斜面の熱収 支の不均衡により形成される流動構造よりも，メソある いはマクロな流動場の影響か湘対的に重要であることを 考慮して，一般風や広域な海陸風との関連について考察 する

\section{2．観測方法}

図 - 1 に関西電力嶺南変電所の位置を示す . 同変電所 は, 福井県美浜町に河口を持つ耳川の河口より約 $6 \mathrm{~km}$ 流の左岸側に位置している . 耳川両岸には , 野坂山地の 標高800 900nの野坂岳, 三国山（右岸側）, 三重嶽，雲 谷山 (左岸側) がせまり, 北北西 - 南南東方向の急峻な 谷となっている。この谷は，峠を越えて，琵琶湖側の滋 賀県マキノ町まて続いており，琵琶湖流域と若狭湾沿岸 を結う渢の通り道となっている。

観測に用いた機器は，(1)ドップラーソーダ風速計：(株) カイジョー社製 A R - 410 (測定方法：3方向モノス タティック方式)，(2)地上風向風速計：(株)小笠原計器製 作所製 C - W 105 (測定方法：ロータリ光エンコーダ 式 (風向)，ブラシレス・パルス式 (風速) ) ，(3)気 温・湿度：(株)小笠原計器製作所製 A - 9100 (測定方 法 : 白金抵抗式 (気温)，毛髮式 (湿度))，(4)日射 量: 英弘精機産業(株製M S - 42 (測定方法: 熱電堆 式），(5)放射収支量 : 英弘精機産業(㹯)製 C N - 1 1，

(測定方法 : 熱電堆・収支式) である.ドップラーソー 父風速計の出力は, 周辺地域の騒音のレベルを考慮して 各日8時〜18時までは900Wで, 18時〜翌日8時までは150 Wに設定されている .

\section{3. 観測結果と考察}

(1) 観測期間の天候概要

観測期間は，2004年9月11日〜26日の16日間である . 天 気図を参照すると, 期間中, 前線を伴う低気圧力澡り返 し日本列島を通過し，全般的に天候は不安定であった . 図 - 2は, 観測ポイント上空の気圧850hPaの高度におけ る, 客観解析データ( GPVデータ)の風速風向時系列を示し ている.この風速值を各観測日毎に単純平均した24時間 平均の風速值を併せて示している . 横軸は時刻であり， 11日0時を原点としている．縦軸は風速と風向であり，風 向について北方を0とする16風向で示している．観測期間 の高層風の卓越風向は南西であり，概ね，南-南西 - 西 の間を変動する。

図－3，4は光れ光れ観測ポイントにおいて観測した 短波放射量と気温の時系列である.参考のために，短波 放射量の日中の最大值は，冬季の平均的好天日で $2 \mathrm{M} / \mathrm{m}^{\mathrm{T} h}$ ， 秋季の平均的好天日で $25 \mathrm{M} / \mathrm{m}$ in程度である .

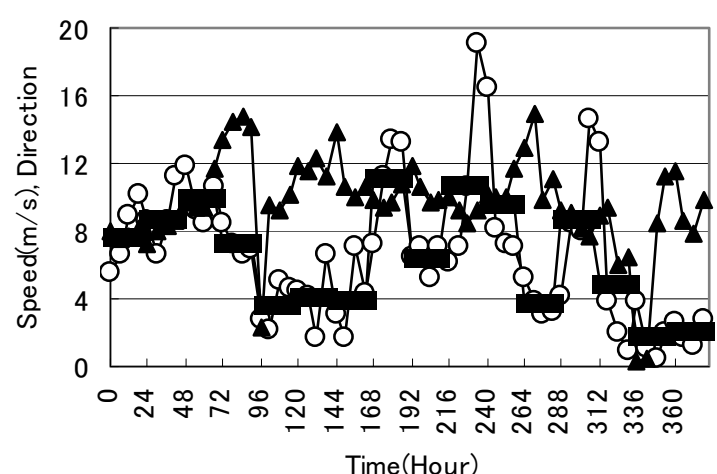

- $-\operatorname{Speed}(\mathrm{m} / \mathrm{s}) \longrightarrow$ Direction $\longrightarrow$ Mean Speed $(\mathrm{m} / \mathrm{s})$

図 - 2 観測地点850hPa高度における風速風向時系列

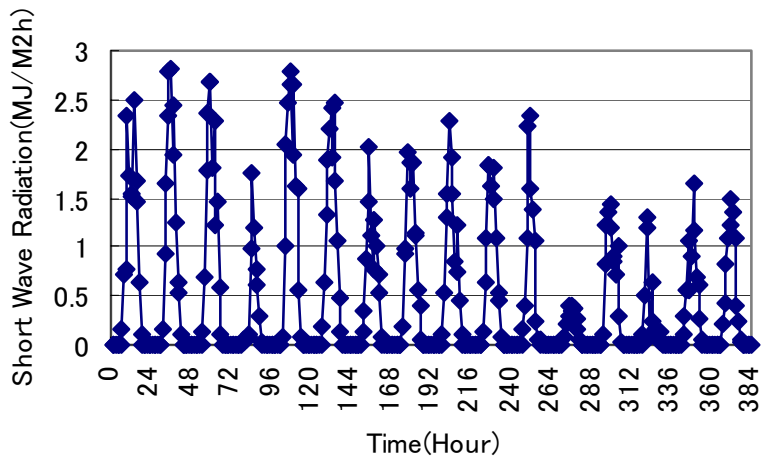

図 - 3 観測地点の短波放射量の時系列

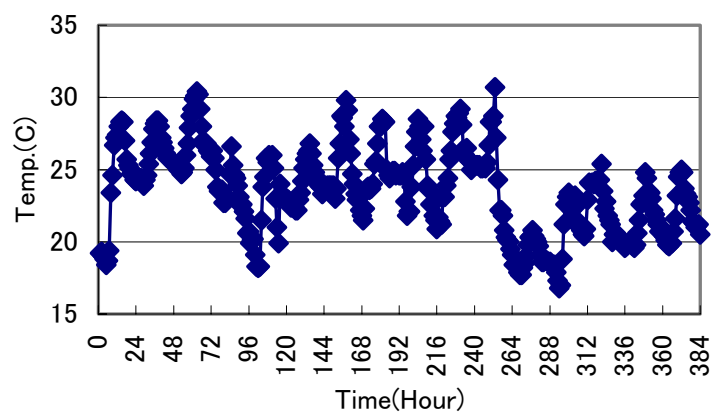

図 - 4 地上気温の時系列

0-96hr (11-14日) は, 相対的に上空風速の大きくなって いる．0.72hr(11-13日) には，勢力の強い高気圧力゙北日本 を通過し, 炎の後, 日本列島の東の太平洋上に高気圧, 西側の東シナ海あるいは日本海において低気圧という気 圧配置に移行する . この期間の高層風速は，高気圧の縁 を回る地衡風によるものであるが，高気圧 - 低気圧の位 置関係の変化によって, 南から南西風へと移行している． 72-96hr ( 14日) には，低気圧に伴う東西に伸びる前線が通 過，風速は急激に南西より北西へと変化している．前線 の通過により短波放射力抑制され，さらに北からの冷気 が流入したことにより，地上気温が急降下している．観 測ポイントの地表気温は，85h(14日13時)の26. 6゚Cから， 102h(15日6時)の18. 1ㄷに急降下している . アメダスデー 
タによれば, 同じ時間に, 琵琶湖岸の虎姫においても， 26. $5^{\circ} \mathrm{C}$ から $16.7^{\circ} \mathrm{Cに}$ に降下しており, 冷気が琵琶湖に達し ていることがわかる . 前線通過後の96-168hr (15 17日)の 期間は, 移動性高気圧か北日本を通過し，概ね好天力続 いている．気圧勾配も比較的小さく，高層風も弱くなつ ている . 高層風向については，96-120hr (15日) は概ね南 西，120-144hr (16日) は西，144 168hr (17日) は南西と なっている.168264(1821日)の期間は，気圧の谷や前 線の通過により，高層風速は比較的大きくなっている． 168 192hr ( 18日)の日平均風速は10m/sを超えており，風 向は概ね南西である.192 216 19日) は南西7m/s，216240hr ( 20日) と 240-264hr (21日) は概ね南西風で風速 10m/s以上である . 264 288hr (22日) には，寒冷前線通過 後に前線に向かう北風が入り，午前10時頃から天候か急 変，地上気温が急下降している．288 336hr (23 24日) は， 前線が停滞あるいは移動して, 風向, 風速ともに変動が 激しい . 336-384hr ( 25-26日) は, 北方の高気圧と南岸の 停滞前線に挟まれた形になるが，東西に伸びる等圧線は こみあっておらず風速は小さい . 336-360hr ( 25日) の風向 は，午前中北，午後南〜西である.360-384hr (26日) は概 ね西風である．

仮に高層風速 $4 \mathrm{~m} / \mathrm{s}$ 以下であることを海陸風発生可能性 の基準とすれば，15日(96-120hr)，16日（120-144hr ），17 日( 144 168hr) ，22日( 264 288hr )，25日(336-360hr)，26 日( 360-384hr) である．22日は短波放射量力極端に少なく 可能性はない，また，気象庁データ4を参照すると，観測 期間の若狭湾付近の海面水温は $25^{\circ} \mathrm{C}$ 程度である . 観測地

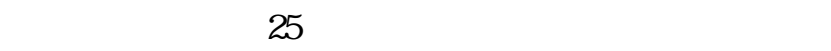
に加えれば，144-168hr (17日)あたりが最も有望である . 以下では，このことを念頭に置いて検討を進める．

（2）地上風観測データ

図一 5 は, 弚れ光れ嶺南発電所の地上風向の時系列で ある.144 168hr (17日) では夜間に南風，昼間に北風とい う風向変化力認められ, 海陸風の風向日変化と一致して いる.このような日変化を示した日は，73 96hr (14日)， 96-120hr (15日), さらに, 多少, 変動傾向の異なるもの も含めれば，240-264hr (21日) , 288 384hr ( 25 26日) も含 まれる . 既述の高層風風速からの海陸風発生可能日から 漏れたのは120-144hr (16日)，新たに付け加わったのが . 240-264hr (21日) である.14，21日には，寒冷前線が通過 しており，この影響により風向か変化したと考えられる

図- 6 は, 観測地点の地上風速の時系列と, 地上風速 と高層風速の相関值の時系列を示している . 高層風速は 6 時間毎のデータであり，光の時系列は 6 時間より短い 時間スケールの現象を表現しない，光こで, 地上風速に ついても 6 時間平均值を求め, 次式より相関值を求めた

$$
\text { Coef }_{i}=\frac{\left(u_{i}-U\right)\left(v_{i}-V\right)}{\sum_{i=1}^{N}\left[\left(u_{i}-U\right)\left(v_{i}-V\right)\right] / N}
$$
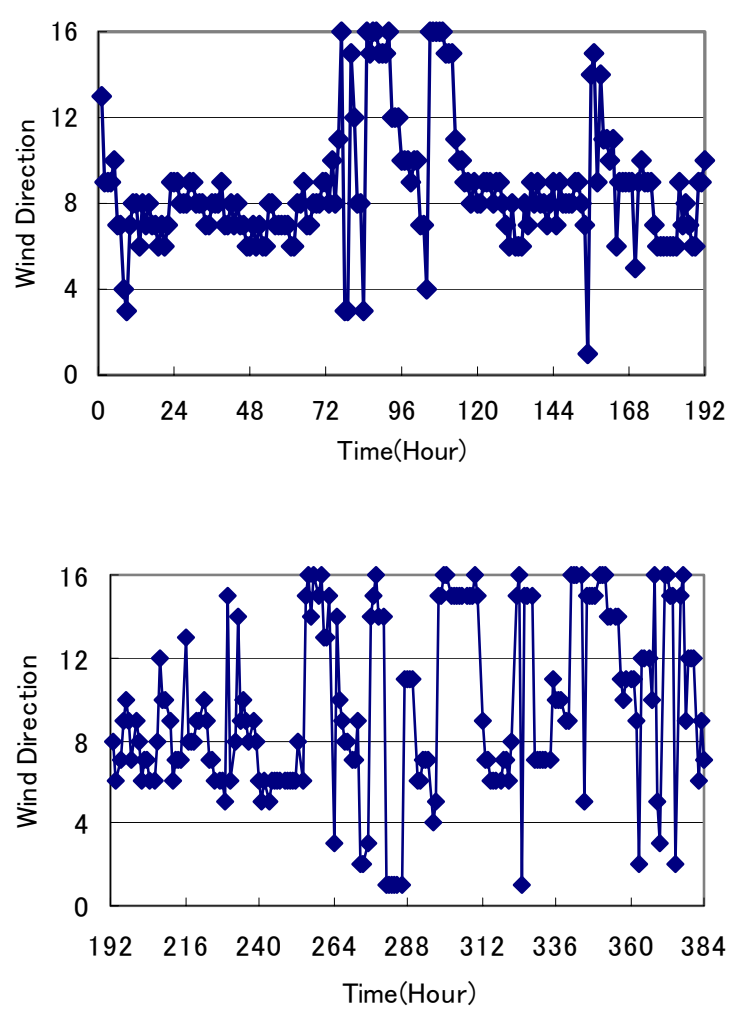

図 - 5 観測期間地上風向

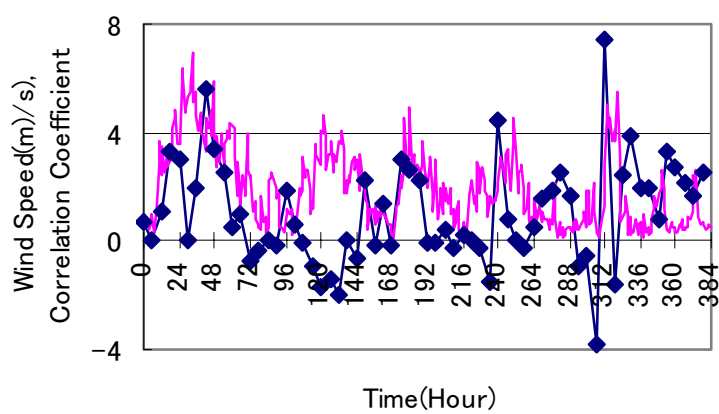

$\neg$ CORRELATION —WIND SPEED $(\mathrm{m} / \mathrm{s})$

図- 6 地上風速と光の上空風速との相関関係

ここに, Coef $f_{i}$ : 第 $\mathrm{i}$ 番相関值, $u_{i}$ : 第 $\mathrm{i}$ 番地上風速值， $v_{i}$ : 第 $\mathrm{i}$ 番高層風速值， $U$ : 観測期間平均地上風速, $V$ : 観測期間平均上空風速， $N$ : データ数である.この 式は, 地上風速変動と高層風速変動の位相関係を調べて いる. 相関係数は右辺分母により計算されるが, 光の值 は0.42と小さいが, 有意水準1\%て無相関は棄却されてい る . 基本的には, 高層風力強くなる時には, 弚の影響を 受けて地上風速も大きくなる傾向がある.地上風速が小 さくなる場合には，他の何らかの駆動力か支配的になる ために，相関が低下することになる．こうしたことを考 慮すると，既述の傾向から大きく乘離している時間帯は 96-144hr であり，高層風が小さいにも拘わらず，地上風 が大きくなっている . 234hr と306hrにも大きな負の相関 


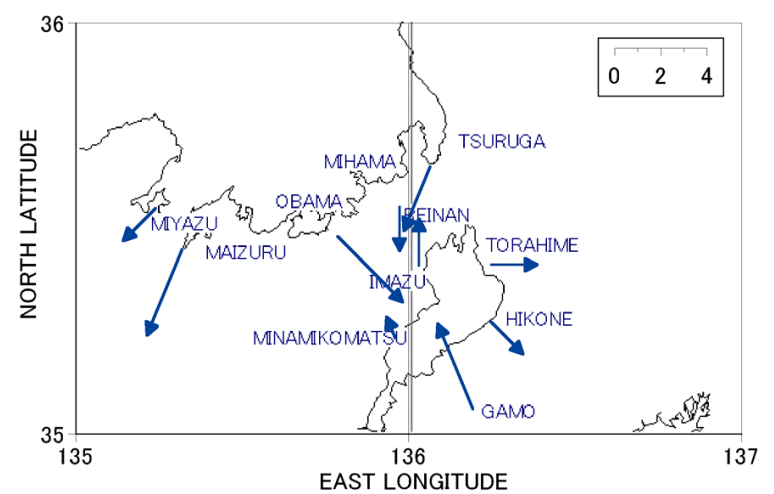

図- 7 111hr (9月15日15時)の風況

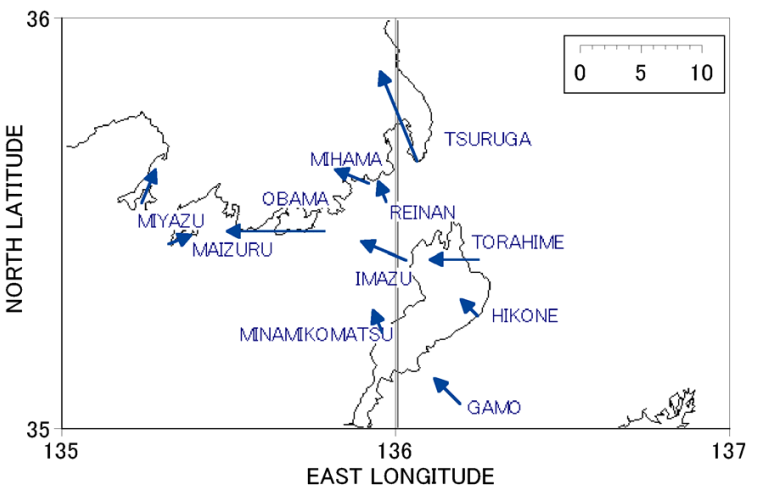

図 - 8 135hr(9月16日15時)の風況

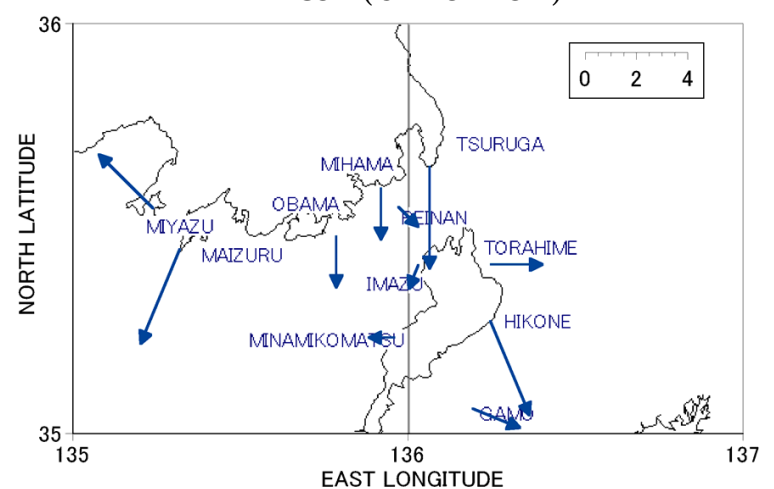

図 - 9 159hr (9月17日15时)の風況

值か現れているが，図－2を参照すると，これらの時刻 に上空の風速值か非常に大きくなっていることがわかる． 地上風がこうした上空風速の急变に追随できなかったこ とによると考えられる . また , 264 360hrでは，全般的に 相関值と地上風速值が逆位相て変動しており, 高層風が 小さいにも拘わらず，地上風が大きくなっている．相関 值変動と地上風変動の位相の逆転は, 既述の寒冷前線の 通過に端を発していると考えられる。

(3) 周辺アメダスデータ

15-17日 ( 96hr - 144hr) の15時( 111hr , 135hr , 159hr) にお ける地上観測データと光の周辺のアメダスデータの風速 ベクトル図を, 図-7〜9に示す.111hrについては, 若 狭湾より内陸方向に, 琵琶湖岸についても湖から陸方向 に吹く湖風力観測されている. 若狭湾の水温が $25^{\circ} \mathrm{C}$ 程度 であるのに対して，111hrの観測地点気温が26゚Cであるこ と，観測地点周辺地域の標高が，観測地点より高いこと， 弚れらにも拘わらず, 若狭湾沿岸地域のアメダスポイン

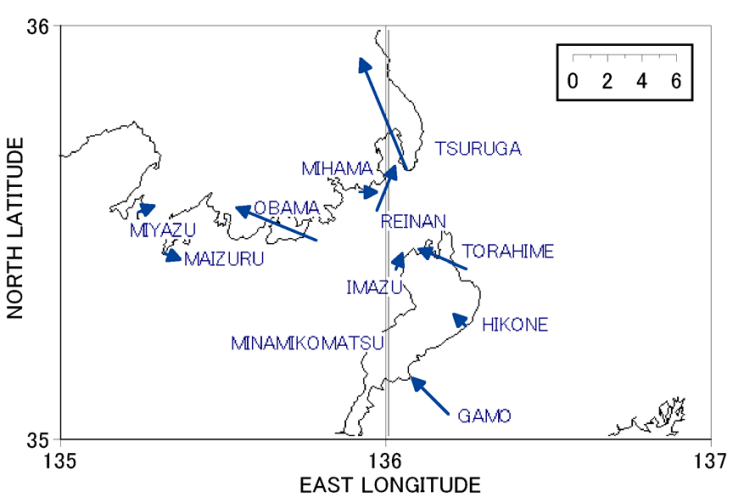

图-10 119hr (15日23時)の風況

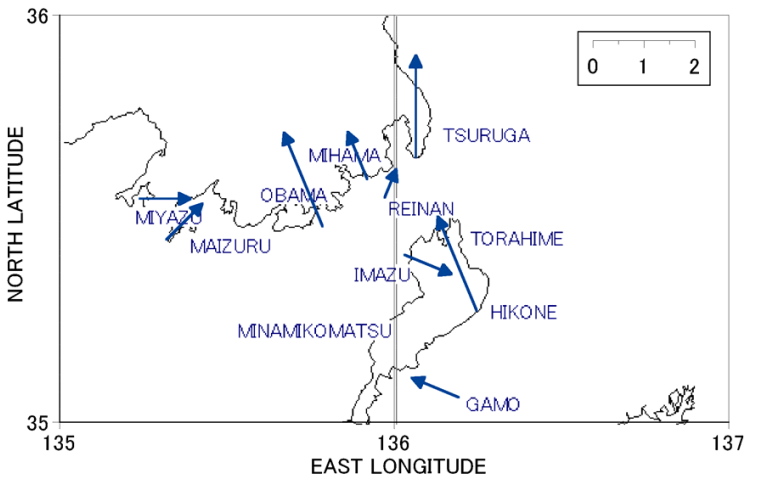

図-11 143hr(17日23時)の風況

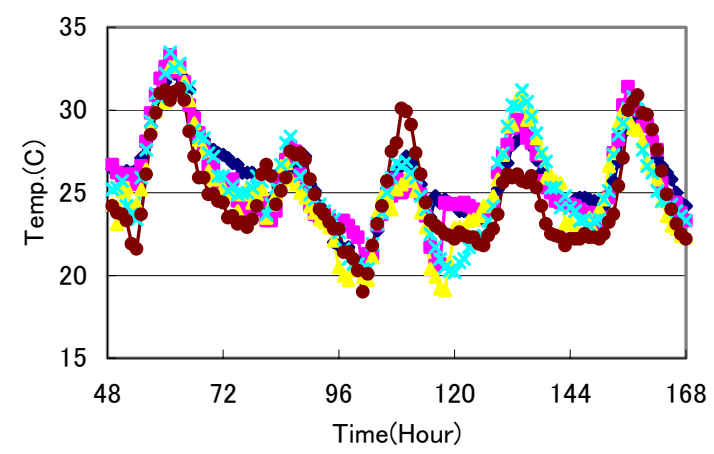

——敦賀 —-小浜 —宮津 $x$ 舞鶴 —蒲生

図-1248 168hr(14 17日)の気温変化

卜において，5m/sを超える風速力観測されてことを考え 合わせると，この流動場が海陸域の温度差に起因する通 常の海風であるとは考えにくい．しかしながら，近江盆 地の中央付近の蒲生を除けば，風速ベクトルの方向は， 観測地点の存在する谷あるいは河川縦断方向に概ね一致 しており，低地を這う密度流であることを伺わせている． 蒲生の風向は南よりになっているが，この方角は高層風 風向と概ね一致している。

135hrでは，111hrに観られたような海風，湖風構造は 観察されず，全体的に南東あるいは南よりの流動となっ ている .この日は , 高気圧か観測点の東方に位置してい ることから，この風向は高気圧の縁を回る地衡風による 影響を強く受けたものであると予想される . 風速べクト ル分布は, 琵琶湖湾岸では比良山あるいは野坂山地に向 かって収束し, 山地を越えて若狭湾付近では発散するよ 


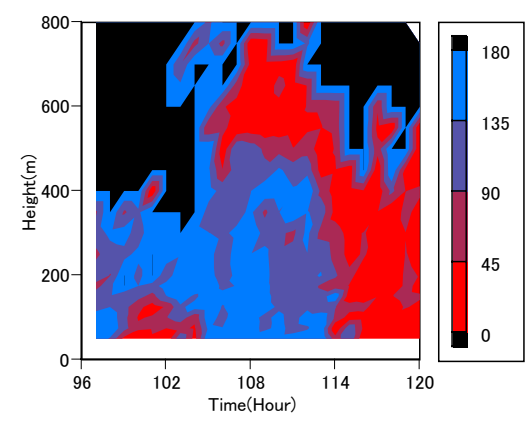

(a) 南北風速

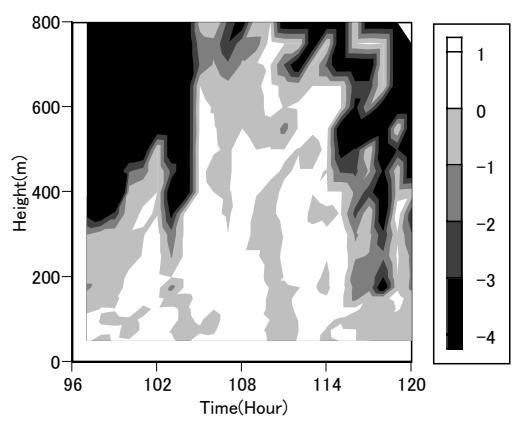

(b) 鉛直風速

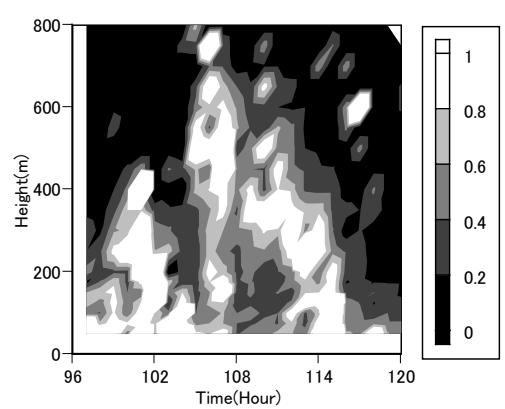

(c) 無次元乱れ強度

図-1396-120hr (15日)の風速鉛直分布 (音波レーダ観測結果)

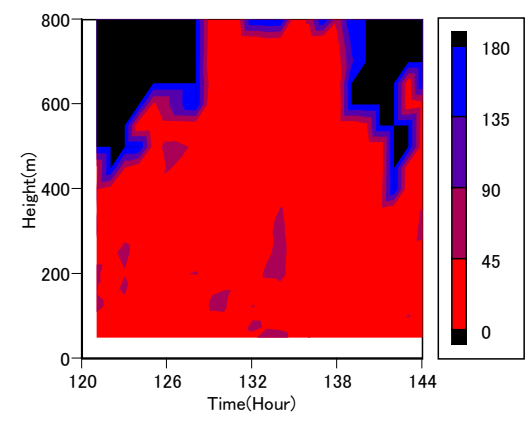

(a) 南北風速

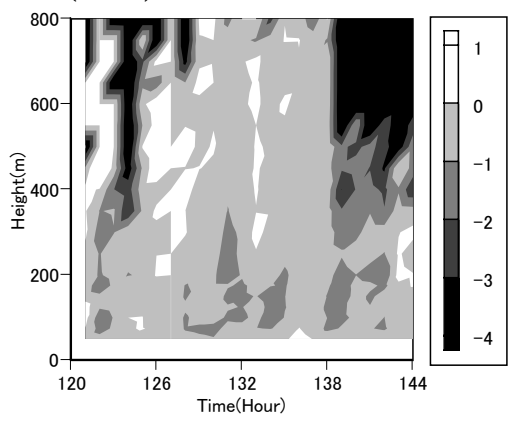

(b) 鉛直風速

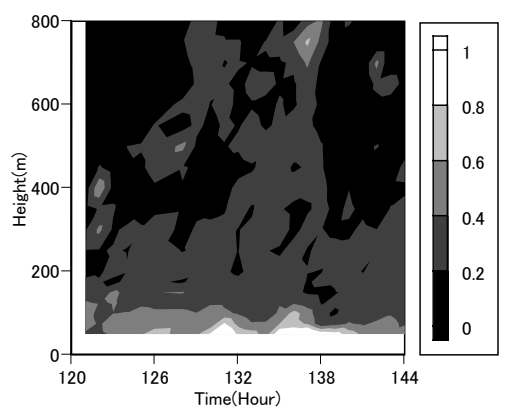

(c) 無次元乱れ強度

図 - 14 120-144hr (16日)の風速鉛直分布 (音波レー夕"観測結果)

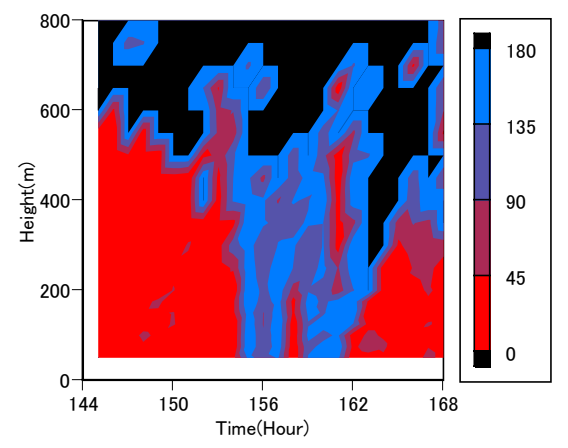

(a) 南北風速

图 - 15 17日

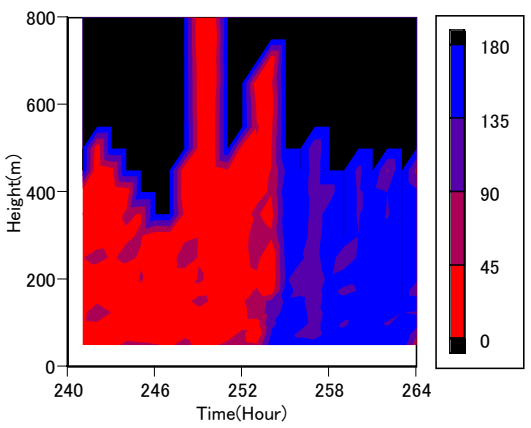

(a) 南北風速

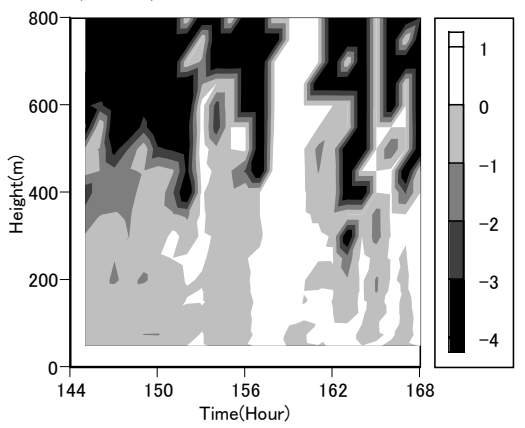

(b) 鉛直風速

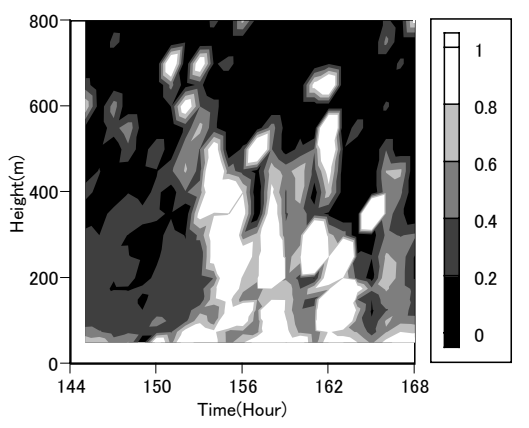

(c) 無次元乱れ強度

144 168hr (17日)の風速鉛直分布 (音波レーダ観測結果)

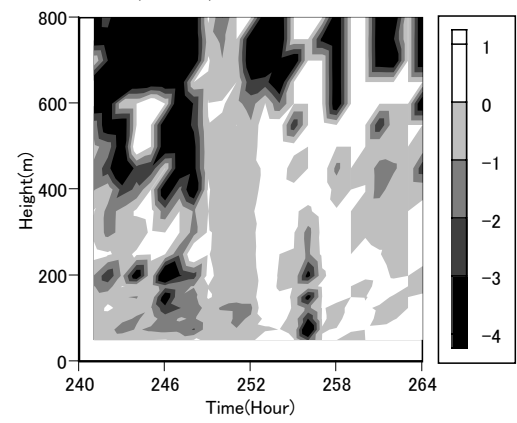

(b) 鉛直風速

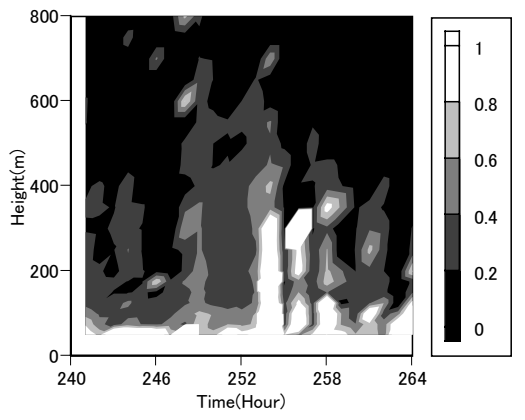

(c) 無次元乱れ強度

图- 16240 -264hr (21日)の風速鉛直分布 (音波レー夕"観測結果)

うな構造となっている .このベクトルを180度回転させれ ば，丁度冬季の琵琶湖湖上卓越風か吹〈場合 5 の風速べク トル図に類似したものになる.気流か琵琶湖や若狭湾付 近を通って，南北方向に通過する場合の典型的な気流八゚ ターンであると考えられる .

159hrについては, 若狭湾から内陸入 , 琵琶湖から内陸 へ向く海風，湖風か形成されているのがわかる.この時 刻の一般風向は南西である.111hr の分布との差異は, 若
狭湾沿岸域のポイントにおいて, 風向か概ね北となって いることであり，谷筋の方向の影響を乥れほど強く受け ておらず，111hr より大きなスケールの流動となっている ことを伺わせる .

次に，15日と17日23时(119hr，167hr)の陸風状況を，光

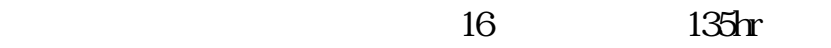
クトル図とほとんど変化がなかったために ここでは割 愛した.119hrにおいて, 琵琶湖や若狭湾方向の陸風力吹 
$\mathrm{N} \longrightarrow$

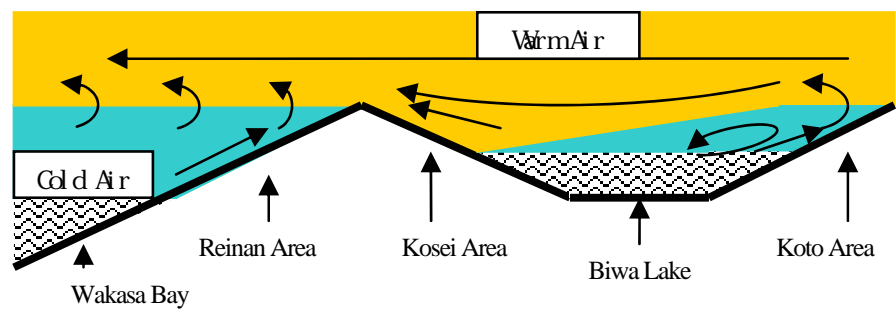

図 - 17 111hr (15日15時)の風況の発生要因

いているものの . 光の風速は4〜 $6 \mathrm{~m} / \mathrm{s} て ゙ あ り ，$ 従来の海陸 風の観測結果と比較して大きい .このベクトル図 - 8に 似ていることから，南よりの一般風の影響が次第に強く なっていく過渡的な状況であると考えるのが良いのでは ないかと考える．一方，167hrのべクトル図では，風速が 弱いながら, 若狭湾, 琵琶湖岸ともに陸風力溌生してい ることがわかる .

図 - 12 は, 観測点周辺のアメダスポイントの72168hr における気温の時系列である .72-96hr ( 14日) に冷 気が入り，各観測点て気温か低下している.96-120hr ( 15 日)では, 近江盆地南方の蒲生に比較して, 若狭湾沿岸域 の各観測点の気温が低くなっているのが，120 144hr ( 16 日)には逆転している . 南方から暖湿気が入って , 太平洋 側で強い降雨があったことから，この気温の逆転は， フェーン現象によるものである.さらに , 若狭湾側の各 アメダスポイントにおいて，113 116hr( 16日17〜20時)に， 気温の急上昇か観られるが，これは南からの暖気の流入 によって, 地表付近の冷気あるいは逆転層力澥消された ことを示している．

(4) ドップラーソーダ風速計測定結果

図 - 13 3 1 6 に音波レーダ風速計で観測した水平方 向風速の風向，鉛直方向風速，水平方向風速の乱れ強度 を風速值で無次元化した無次元乱れ強度の鉛直分布を示 す . 風向は, 南との偏差を示しており，南0, 北180, 東 西90となっている.96120hrにおいて，106hr ( 10時)頃か ら上空に南からの気流が入り，地表から高さ450mまでの 領域で北より気流となっている. 鉛直風速分布から，こ の南風に向かう上昇流となっていることがわかる . 無次 元乱れ強度分布は, 高層南風と低層北風の境界付近で乱 れか発生していることを示している .これらから，前日 の寒冷前線の通過によって流入した冷気による逆転層上 に南方からの暖気が流入し，成層構造となっていること がわかる. 図- 7 の風速べクトル分布, 図- 2 より上空 1500nたおいて南東風となっていること, 図-12の気温 変動などから，二の状況は図-17のように推測される。 成層界面において生じる乱流によって, 冷気が連行され ることが予想される．このような条件下であれば，弱 風・晴天日という必要条件を満足しなくても, 若狭湾海 風・琵琶湖湖風の組み合わせは発生する . 冷たい北風領 域の厚さは，混合により次第に薄くなり，114hr (18時)〜 116hr ( 20時) 頃に , 南風が地上に到達しており， この時刻は, 図-12 において示した気温急上 昇の弚れと一致する．120144hr (16日)におい ては, 全体的に南風が入り，鉛直方向には下降 流が卓越している．底面付近の無次元乱れ強度 が大きくなっており，上空に強い乱れを生成す るような顕著な速度勾配がないことがわかる． 144 168hr(17日)では，154hr ( 10時) 頃に南風 (陸風) が北風(海風)に, 162hr (18時)頃に再度 南風に転換している樣子がわかる . 南風期間で は下降流，陸風期には上昇流，夕刻の南風期には，上昇， 下降を繰り返すような状況となっている．無次元乱れ強 度は海風陸風転換期，あるいは午の逆の場合に，地表付 近で大きくなる。比較のために，図－16に寒冷前線通 過時の南北風向，鉛直方向風速，無次元乱れ強度の鉛直 分布を示している．風向図より，254hr頃に寒冷前線通過 によって, 風向か急激に変化していることがわかる.鉛 直方向風速, 乱れ強度が, 図-15の特徵に非常に一致 している ここしたことからも，154hrの陸風から海風へ の転換が，冷気フロントの通過であることか確認される .

\section{4. まとめ}

本研究では, 福井県嶺南地域の谷において山谷風の観 測を行ない, より広域な一般風との関連性について考察 した . 海陸風の発生には, 弱風・晴天という各日の気象 条件が必要とされるが, 加えて先行条件にも強く影響さ れる.海水温に比較して, 地上気温が十分大きくないよ うな暖候期においては，寒冷前線通過による冷気団の侵 入と炎の後の南方からの暖気による冷気団の解消という 変動パターンが, 海陸風等の地上風況に強く影響するこ とがわかった . とくに冷気層 (逆転層) の形成が , 海風 あるいは琵琶湖の湖風の発生要因になることを示した .

\section{参考文献}

1) 東野晴行, 北林興二, 井上和也, 三田和哲, 米澤義堯 : 曝 露・リスク評価大気拡散モデル(ADMER)の開発，大気環境 学会誌, 第38巻, 第2号, pp.100-115, 2003 .

2) 玉井昌宏，有光剛(2004) : 海陸風を含む模疑気象場における パフ・プルームモデルを用いた大気污染物質リスク評価モデ ルの検証，海洋開発論文集，Vol.20, pp.335-340.

3) 浅野富雄(1996): ローカル気象学, 2海陸風, p.233.11-44, 東京大学出版会.

4) http://www.data.kishou.go.jp/marine/ocean/daily/daily.html

5) 玉井昌宏 - 石井義裕・磯野知信(2001) : 琵琶湖湖上風の数値 シミュレーション, 水工学論文集, 第45巻, pp . 1231-1236.

( 2005. 9. 30受付) 